\title{
A Látrányi Puszta Természetvédelmi Terület egyenesszárnyú rovarairól (Orthoptera)
}

\author{
Nagy BarnabÁs', SzövÉnyi Gergely² és PusKảs GellérT ${ }^{2}$
}
'Plant Protection Institute of the Hungarian Academy of Sciences, H-1525, Budapest, Pf. 102, Hungary, nagybarnabas@julia-nki.hu
${ }^{2}$ ELTE Department of Systematic Zoology and Ecology, H-1117 Budapest, Pázmány P. sétány 1/C., gegesz@ludens.elte.hu

NAGY B., SZÖVÉNYı G. \& PUSKÁs G.: Grasshoppers (Orthoptera) of the Látrányi Puszta Nature Conservation Area (W Hungary)

Abstract: In the mosaic of xerophilous sandy hills and mesophilous meadows (near to the Lake Balaton) 33 Orthoptera species ( 13 Ensifera and 20 Caelifera) were detected. These Orthoptera assembladges are relatively poor in true sandy steppe species.

Key woords: Orthoptera fauna, W Hungary, biodiversity, density, zoogeography

\section{Bevezetés}

Orthopterológiai vonatkozásban a Balatontól délre eső területek, így Somogy és Tolna megyék is a gyengén, vagy közepesen kutatott területek közé tartoznak. Ezen belül a Látrányi Puszta Természetvédelmi Területröl (LP) korábbi orthopterológiai adatot alig találunk (ÁBRAHÁM 1992). Somogy megye állatvilágának újabb keletü felmérésében (ÁBRAHÁM 2001) a látrányi területről mindössze egy futólagos nyár végi gyüjtés alapján tudtunk tájékozódni (NAGY és SzÖVÉNYI 2001). Az ekkor végzett gyüjtés faunisztikailag legmeglepőbb eredménye a déli dobolószöcske (Meconema meridionale) magyarországi harmadik lelöhelyének kimutatása (NAGY 2001). Ezt követően néhány további, 20012002-ben végzett mintavételezés most már lehetővé teszi, hogy elfogadható képet adjunk Látrány környékének Orthoptera-faunisztikai viszonyairól, noha a nedves területekről, kaszálókról és a lápos rétekről még további gyüjtések szükségesek a teljesebb kép kialakításához.

\section{Anyag és módszer}

A látrányi homokpusztára az utóbbi két évtized folyamán figyeltek fel és 1992-ben vált kijelölt védett területté. Geomorfológiailag egyike a Dél-Dunántúl kisebb-nagyobb kiterjedésü homokdombos foltjainak, amelyek xerofil, xeromezofil lejtői az LP-en belül az Orthoptera-együttesek legfontosabb habitatjai, ugyanakkor a kis kiterjedésü $(223,6$ ha) területhez viszonyítva számos más, föleg nedvesebb jellegủ habitat (rét, kaszáló, lápos, mocsaras folt) is található, amelyek további Orthoptera-fajoknak adnak élöhelyet. 
A LP Orthoptera-faunájának feltárása több részletes mintavételezés, továbbá néhány alkalmi gyüjtés alapján történt (1. táblázat). Az egyenesszárnyú rovarok leglényegesebb élöhelyeinek megfelelöen a mintavételezések többségét xerofil, xeromezofil jellegü habitatokban végeztük (2. táblázat). Összehasonlításképpen csatoltunk egy, az LP-tól kb. 60 km-re keletre lévő homokpusztai élőhelyről (Bikács: Ökör-hegy) származó felvételünket is (9. táblázat).

A gyüjtés túlnyomóan kaszáló-hálóval történt, kiegészitve egyeléssel és lombozatról való kopogtatással. Az utóbbi módszernek volt köszönhető a ritka Meconema meridionale megtalálása is.

Táblázatainkban a fajok jelenlétét kétféle módon jelöltük. Tüzetesebb felvételek esetében a jelentősebb egyedszám lehetővé tette az együtteseket alkotó fajok \%-os részvételi arányának megállapítását. Kisebb volumenü, illetve kevésbé alapos gyüjtés esetén a faj jelenlétét + jellel jelöltük. A táblázatokban csak genusz névvel feltüntetett taxonok lárva-állapotuk miatt fajilag nem voltak biztosan meghatározhatók

A nomenklaturában és a fajok sorrendjében HELLER et al. (1998) összeállitását követtük.

1. táblázat: A Látrányi Puszta Természetvédelmi Terület Orthoptera-faunájának feltárására végzett gyüjtések áttekintése

\begin{tabular}{|c|c|c|l|}
\hline Mintavétel száma & Észlelt fajok & \multicolumn{1}{|c|}{ Idõpont } & \multicolumn{1}{|c|}{ Felvételezõ } \\
\hline 7 & 20 & 2000 . IX. 14. & Nagy B. \\
\hline 3 & 19 & 2001. VII.1 -3 & Szövényi G. \\
\hline 2 & 15 & 2001. VII 10. & Kondorossy E. \\
\hline 2 & 9 & 2002. VII. 19. & Kondorossy E. \\
\hline 8 & 30 & 2002. VIII. 28. & Szövényi G. \\
\hline
\end{tabular}

2. táblázat. A mintavételek megoszlása a látrányi terület fontosabb élőhelyi típusai szerint

\begin{tabular}{|l|c|c|}
\hline Ǵóhely-típus & Felvételek száma & Fajok száma \\
\hline Xerofil lejtõ, legelõ & 8 & 24 \\
\hline Mezofil rét, kaszáló & 2 & 14 \\
\hline Higrofil (láp)-rét & 3 & 11 \\
\hline Erdõszéli bokros & 4 & 12 \\
\hline Egyéb & 4 & 15 \\
\hline Összesítés: & 21 & 33 \\
\hline
\end{tabular}

Eredmények és értékelésük

\section{Faji diverzitás}

A Látrányi Puszta Természetvédelmi Területen a 2000-2002-ben végzett gyüjtések alapján 33 Orthoptera-faj előfordulását mutattuk ki (10. táblázat). Ez a fajszám a Somogy megyéböl kimutatott 57 faj (NAGY és SzÖVÉNYI 2001) 58 \%-át képviseli, amely nem jelent különösebben figyelemre méltó fajgazdagságot, hanem nagyjából megfelel a terület kiterjedésének és élőhelyekben való változatosságának.

Fajokban leggazdagabb Orthoptera-együtteseket az LP területén is a homokpusztai élőhelyeken találtuk még abban az esetben is, ha azok másodlagosak, vagy némileg za- 


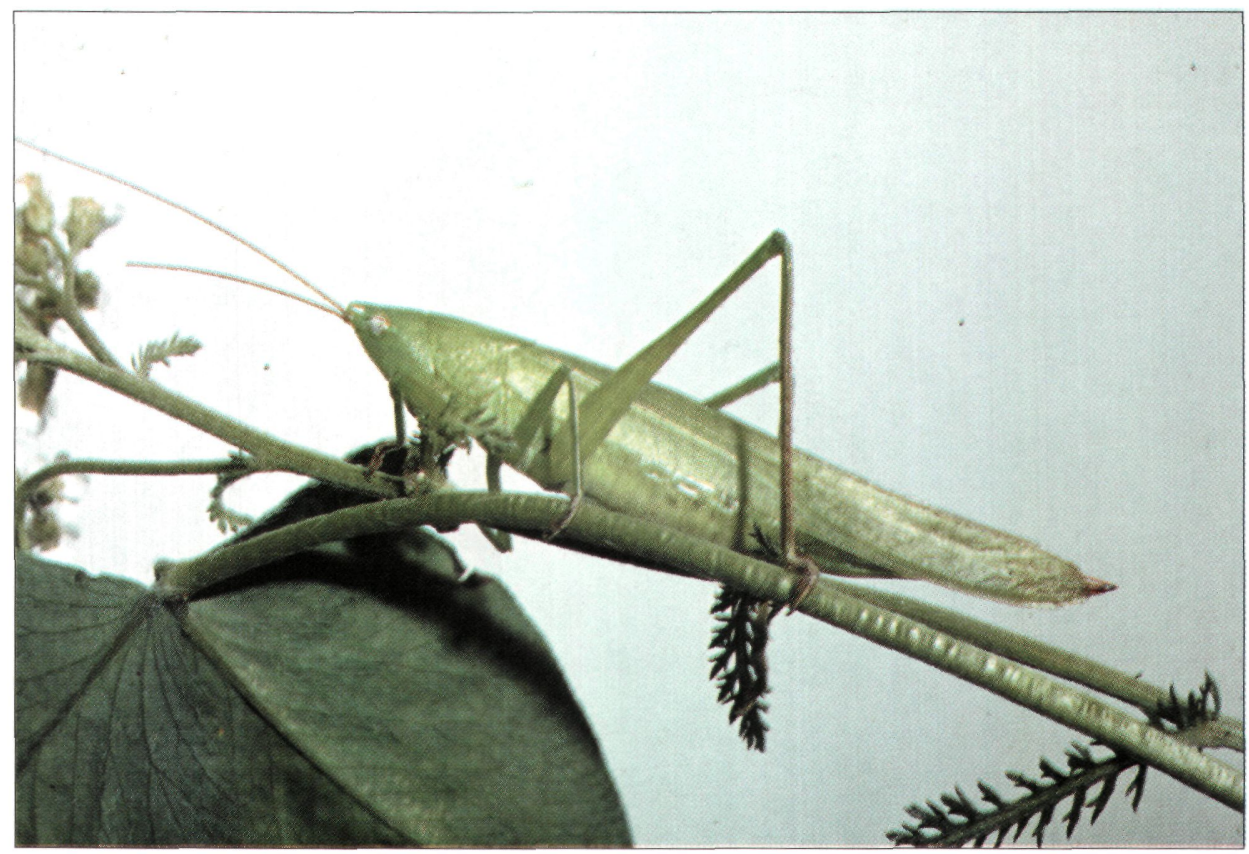

1. ábra: Nagy kúpfejűszöcske (Ruspolia nitidula) nősténye. Fő élőhelye a vizenyős, sásos rét, de elég jó repülő és így szórványosan szárazabb helyekre is eljut. Fotó: Nagy B.

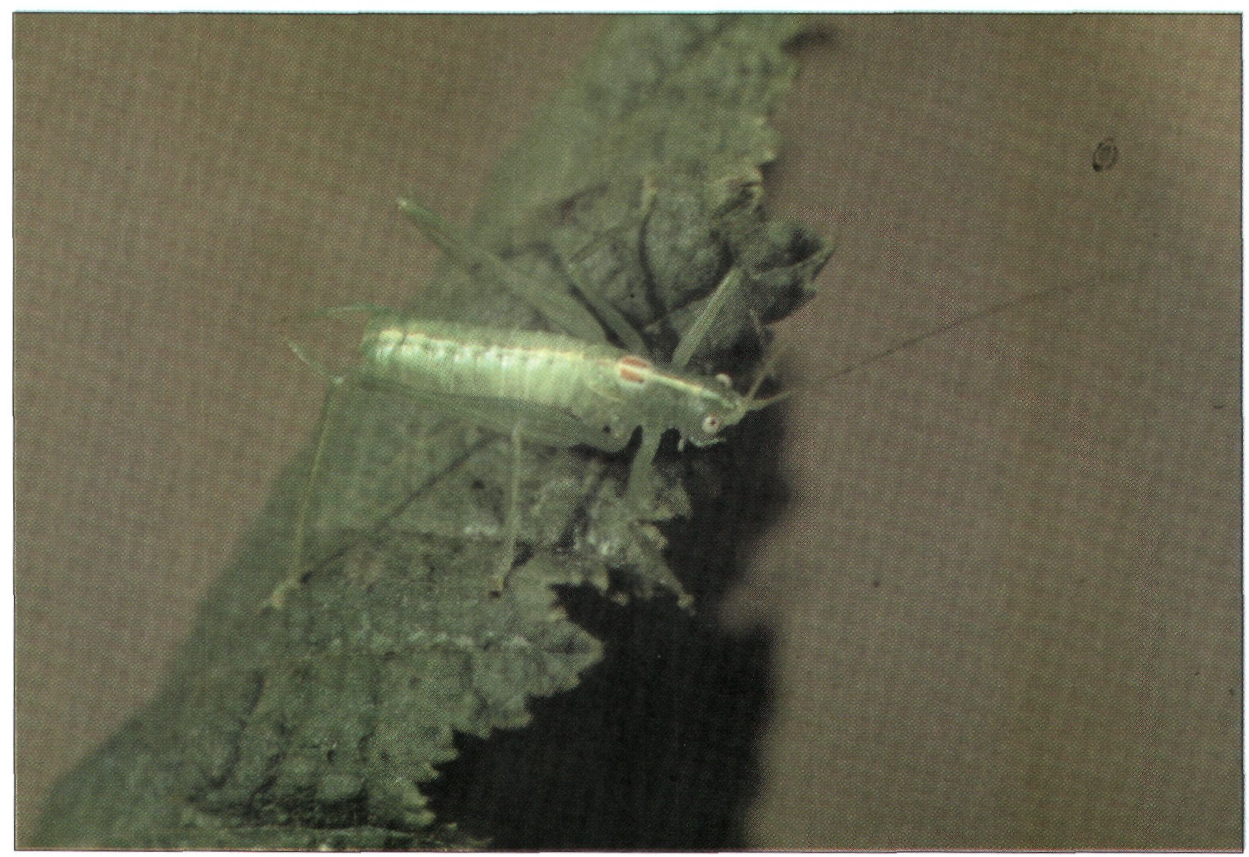

2. ábra: Déli dobolószöcske (Meconema meridionale) hímje. Magyarországról még alig ismert; Látrány a harmadik hazai lelőhelye. Fotó: Nagy B. 


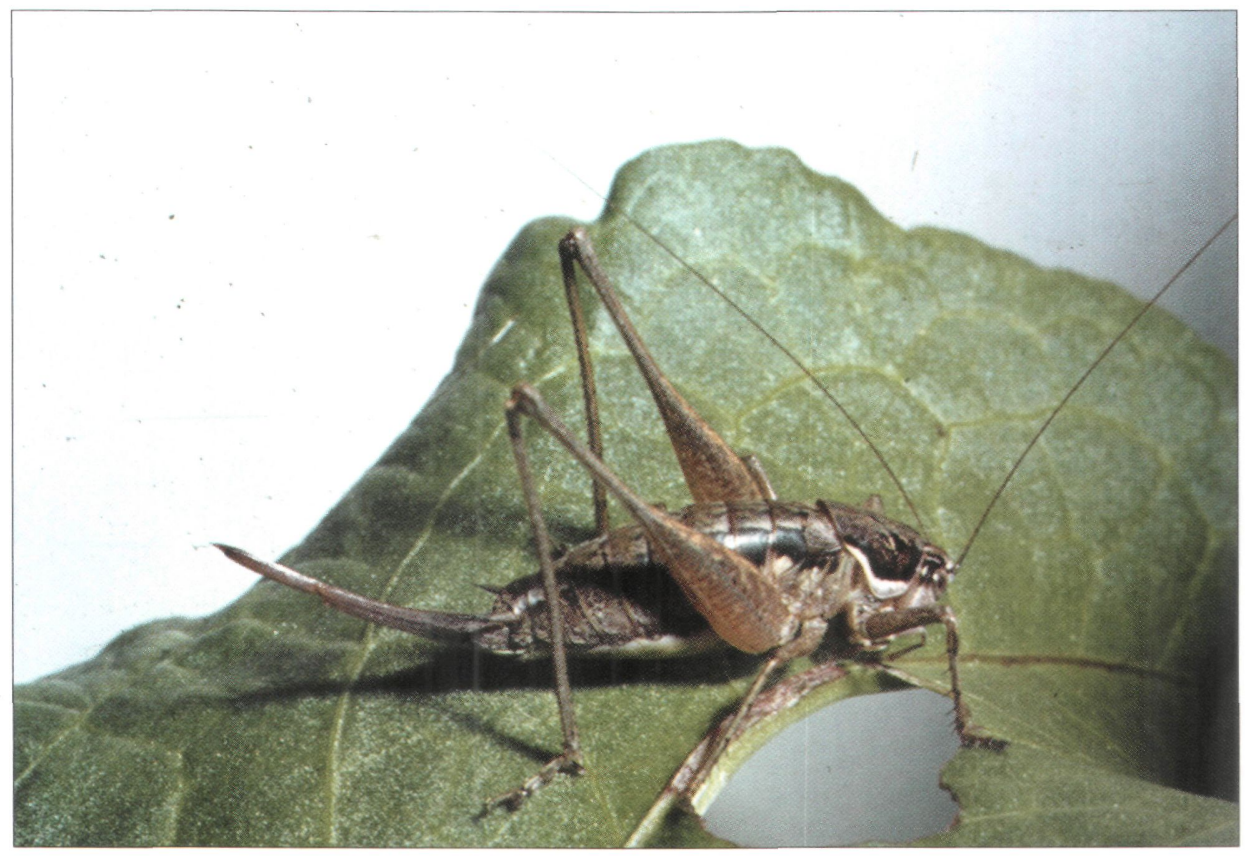

3. ábra: Karcsú szöcske (Pachytrachis gracilis) nősténye. Látrány környékén ritka, mert elsősorban dombvidéki faj. Fotó: Nagy B.

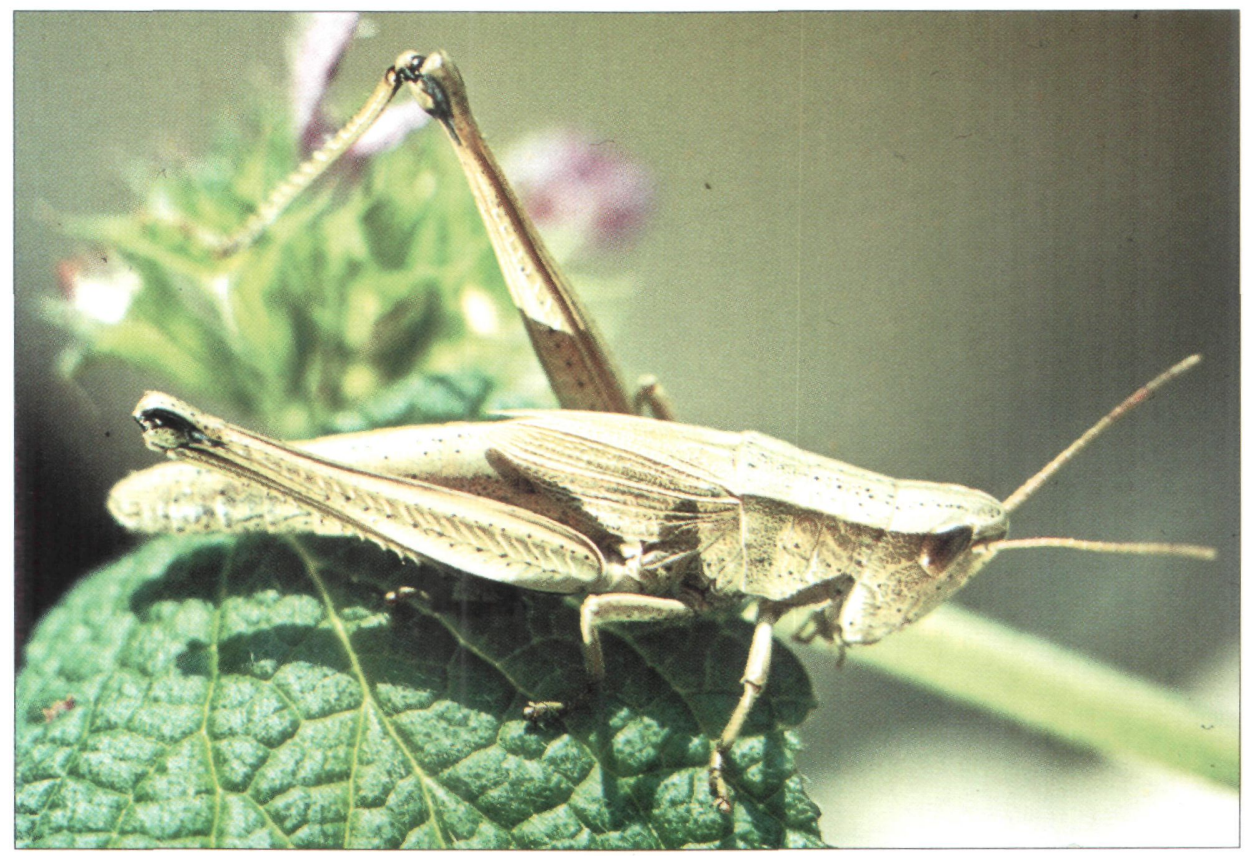

4. ábra: Aranyos sáska (Chrysochraon dispar) nősténye. Nedves élőhelyek állata; magyar neve inkább a hímre jellemző. Fotó: Nagy B. 
vartak (legelök) voltak. E túlnyomóan xerofil élőhelyeken a "csúcsidőben" maximálisan 11-16 faj volt kimutatható és még szeptember végén is 8-10 fajból álló együtteseket találtunk.

A mezofil és higrofil élőhelyek a látrányi területen viszonylag kis fajszámmal és kevés jellegzetesebb Orthoptera-fajjal szerepeltek. Valószínü, hogy eddigi gyüjtéseink nem voltak elégségesek e típus tökéletesebb megismerésére, vagy legalábbis olyan fajok (Mecostethus, Stetophyma, Chorthippus montanus) hiányának magyarázatára, amelyek a Dunántúl más hasonló jellegü habitatjaiból általában nem hiányoznak. Egyébként is Magyarországon a higrofil típusú élőhelyek - a xerofilokhoz viszonyítva - általában fajszegényebbek.

A különböző típusú élőhelyek kis kiterjedése és mozaikossága tükröződik abban a jelenségben, hogy az eltérö ökológiai igényü fajok esetenként egy-egy habitatban együtt mutatkoznak. Igy pl. a Platycleis montana homokpusztai szöcske és a Pezotettix giornae mezo-xerofil jellegü mediterrán sáska szórványosan lápréti folton is elökerült. Hasonló jellegü "keveredés" eltérő ökológiai igényü, de jól, vagy közepesen repülö szárnyas fajok esetében (Phaneroptera, Ruspolia, Conocephalus) - éppen az említett élöhelyi mozaikosság következtében - már kevésbé meglepő.

\section{Állatföldrajzi értékelés}

A LP Orthoptera-faunája csak kevés olyan fajt tartalmaz, amelyek alapján élesebben el lehetne különíteni földrajzi környezetétöl.

A Myrmeleotettix antennatus sáska a Kárpát-medencében homokpuszták indikátor fajaként tartható számon és ebben a minőségében a LP-beli előfordulása szigetszerü. Lokális jelentőségét kiemeli az a körülmény, hogy a Balaton vonalától ÉNy-ra már csupán a Gönyü környéki homokpusztákon fordul elö. Hasonló "pusztai" faj a Platycleis montana szöcske is, amely kötött talajú élöhelyeken, pl. a Hortobágyon is meg van.

A fa/bokor-lakó, mediterrán déli dobolószöcske, Meconema meridionale az utóbbi 12 évtizedben történő észak felé nyomulása - egészen Hollandiáig - jól ismert (KLEUKERS et al. 1997), azonban az utóbbi évtizedben megtalált három dunántúli lelőhely kontinetálisabb ÉK irányú terjeszkedésére utal (SzIRÁKI 1996, NAGY 2001). A különös area kiterjeszkedést e faj esetében elsősorban antropochoriával magyarázzák, azonban a nem közvetlenül a fö közlekedési útvonalak melletti - dunántúli elöfordulási pontok nem erösítik ezt a feltevést, noha a fö közlekedési útvonalak mentén végzett erre vonatkozó vizsgálatok a Dunántúlon még hiányoznak.

A Pacytrachis gracilis brachypter szöcske LP-beli elöfordulása némileg meglepő. Törvényszerü, bár nem túl gyakori előfordulását általában domb- és hegyvidékeinkről ismerjük. Ennek megfelelően a Balaton északi oldalán húzódó dombvidéken és a Bakonyban már több pontról kimutatták (RÁCZ 1979). A Balaton-felvidéki Nemzeti Park területén viszont már számos egyéb - a LP-ból hiányzó - Orthoptera-faj honos volta éles zoogeográfiai elkülönülést jelent (NAGY 1948, RÁCZ 1979).

A Duna-Tisza-közi kiterjedt homokpuszták gazdagabb Orthoptera-faunájától eltekintve, a dunántúli homokos talajú élöhelyek közül csak kevés összehasonlítási alapot találunk. Így pl. a Fenyőfö homoki élőhelyeiről az eddig kimutatott Orthoptera-fajok száma ugyan nem éri el a látrányit, azonban az ottani Acrotylus longipes Charp. előfordulás zoogeográfiailag igen figyelemre méltó: nevezetesen a legnyugatibb - és egyben teljesen elszigetelt - kárpát-medencei előfordulást jelenti (RÁCZ 1979). Ugyanakkor a látrányi területnek is megvan a maga különleges - és szintén déli kapcsolatokra utaló - Orthopterafaja, a fentebb már értékelt Meconema meridionale, amelynek a LP a harmadik magyarországi lelöhelye. 
3/A. táblázat. Az Orthoptera népesség becsült denzitása a Látrányi Puszta

Természetvédelmi Terület néhány mintavételi élöhelyén (2000. IX. 14.)

\begin{tabular}{|l|c|c|c|}
\hline Gónhely & $\begin{array}{c}\text { Denzitás } \\
(\text { példány/m²) }\end{array}$ & $\begin{array}{c}\text { Növényzeti } \\
\text { borítás \% }\end{array}$ & $\begin{array}{c}\text { Növényzeti } \\
\text { magasság, cm }\end{array}$ \\
\hline Homoki sztyeprét(degradált, zavart) & $0,8-1,2$ & $70-95$ & $15-30-(45)$ \\
\hline Homoki (marha) legelõ (Cynodon) & $2,5-3,0$ & $70-80$ & $7-15-(25)$ \\
\hline Homoki (juh) legelõ (Cynodon, Andropogon) & $2,5-2,8$ & $65-75$ & $8-15-(25)$ \\
\hline Homoki (Kolláti) legelõ (Cynodon, zavart) & $(0,7)-1.0-1,5$ & $60-80$ & $20-40$ \\
\hline
\end{tabular}

3/B.táblázat. Az Orthoptera népesség becsült denzitása a Látrányi Puszta

Természetvédelmi Terület néhány mintavételi élöhelyén (2002. VIII. 28.)

\begin{tabular}{|l|l|c|}
\hline Hely megjelölés & Éôhely & Denzitás (példány/m² \\
\hline Kolláti-legelõ & Nyílt homoki gyep & $6-8$ \\
\hline Kökörcsines-domb & Nyílt homoki gyep & $8-10$ \\
\hline Birka-legelõ & Homoki gyep Stipa-val & 0,5 \\
\hline
\end{tabular}

A látrányi másodlagos jellegü homokpusztai habitatok Orthoptera-faunáját egybevethetjük még a - földrajzilag az LP és a Duna-Tisza-közi homok-hátság közé eső - Bikács helység keleti határában lévö Ökör-hegy $(150 \mathrm{~m})$ faunájával, ahol 1995-ben gyüjtöttünk. $\mathrm{Az}$ egy alkalommal, de igen megfelelő időben (VII.26.) történt mintavételezés arra mutat, hogy a nagyobb kiterjedésü és kevésbé zavart Ökör-hegy - több jellegzetes homokpusztai faj jelenléte folytán - csaknem megközelíti a Duna-Tisza-közi homokpuszták Orthoptera-faunáját és együttesbeli összetételét (9. táblázat). Az Ökör-hegyröl kimutatott - homokpusztai indikátor-fajoknak tekinthető - Stenobothrus fischeri, Calliptamus barbarus, Sphingonotus caerulans sáskák vizsgálatunk három éve alatt sem kerültek elő az LP-ről. A kis-alföldi homokpusztai élőhelyekre jellemző fajok közül ARADI (1955) az Acrotylus insubricus sáskát említi, bár lehetséges, hogy a Calliptamus italicus adatai között szerepelhet az akkor még bizonytalanul elkülönített $C$. barbarus faj is. Ezt valószínüsíti, hogy később meg is találtuk Györszentiván határában (1997, leg. Szövényi G.).

Végeredményben tehát megállapitható, hogy a látrányi homokpusztai élöhelyeken a Duna-Tisza-közi Orthoptera-fauna néhány lényeges karakterfaja hiányzik.

\section{Denzitási viszonyok}

A mintavételezések egy részében (2000. IX. 14.) az Orthoptera-népesség egyedsürüségi becslésére is sor került. Az élőhely-típusok között ez esetben is a homokdombok xerofil élöhelyein mutatkozott jelentősebb denzitás, amely többszörösét tette ki a dúsabb növényzetü mezofil, higrofil réteken található Orthoptera népességnek (3/A. táblázat). Tekintettel arra, hogy az Orthoptera fajok többsége május-júniusban kel ki, az itt közölt, szeptember közepi denzitás értékeket jóval meghaladó egyedsürüség tételezhető föl június végén. Erre utal néhány augusztus végi jelentős $-6-10 / \mathrm{m}^{2}$ példányig fölmenő denzitási adat is (3/B táblázat). 


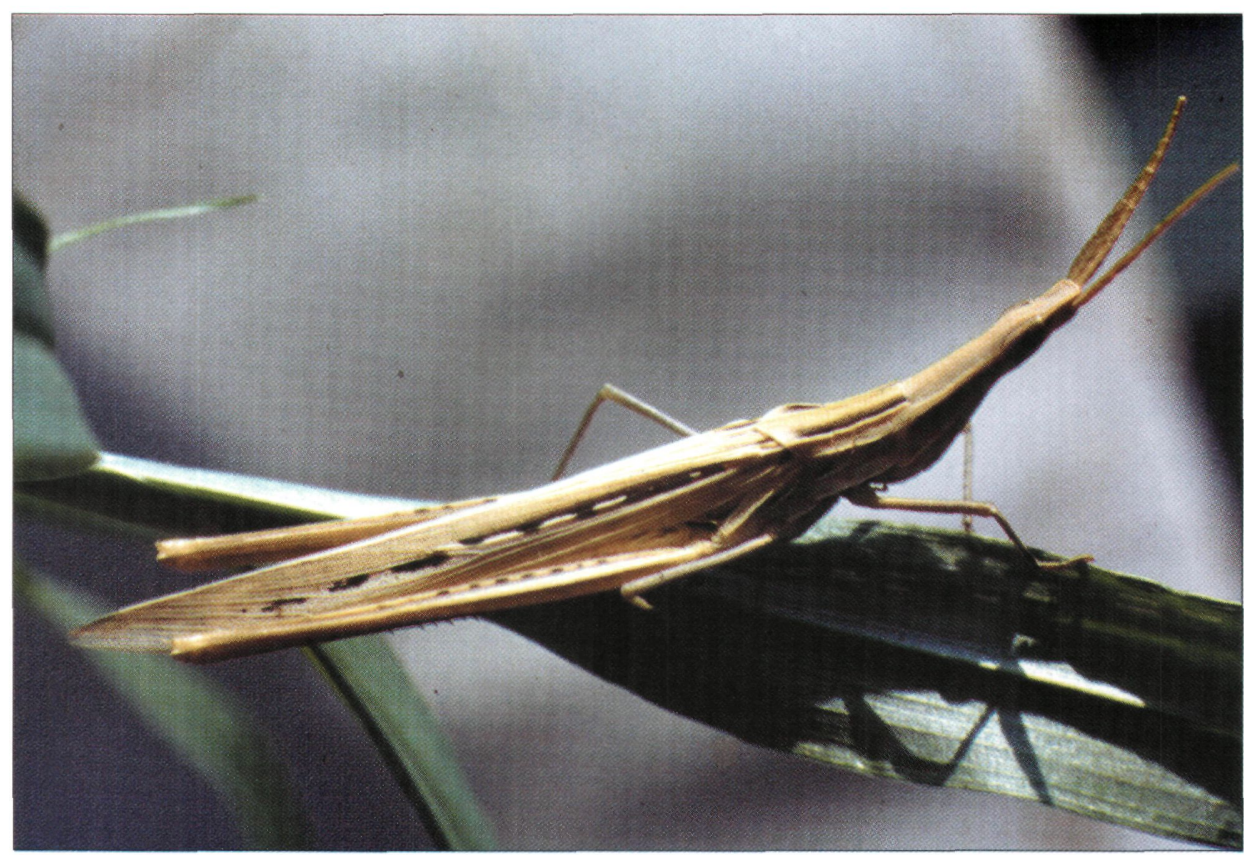

5. ábra: Sisakos sáska (Acrida ungarica) nőstényének barna szinezeti típusa. A látrányi területen ez idő szerint az egyetlen "védett" Orthoptera-faj. Foto: Nagy B.

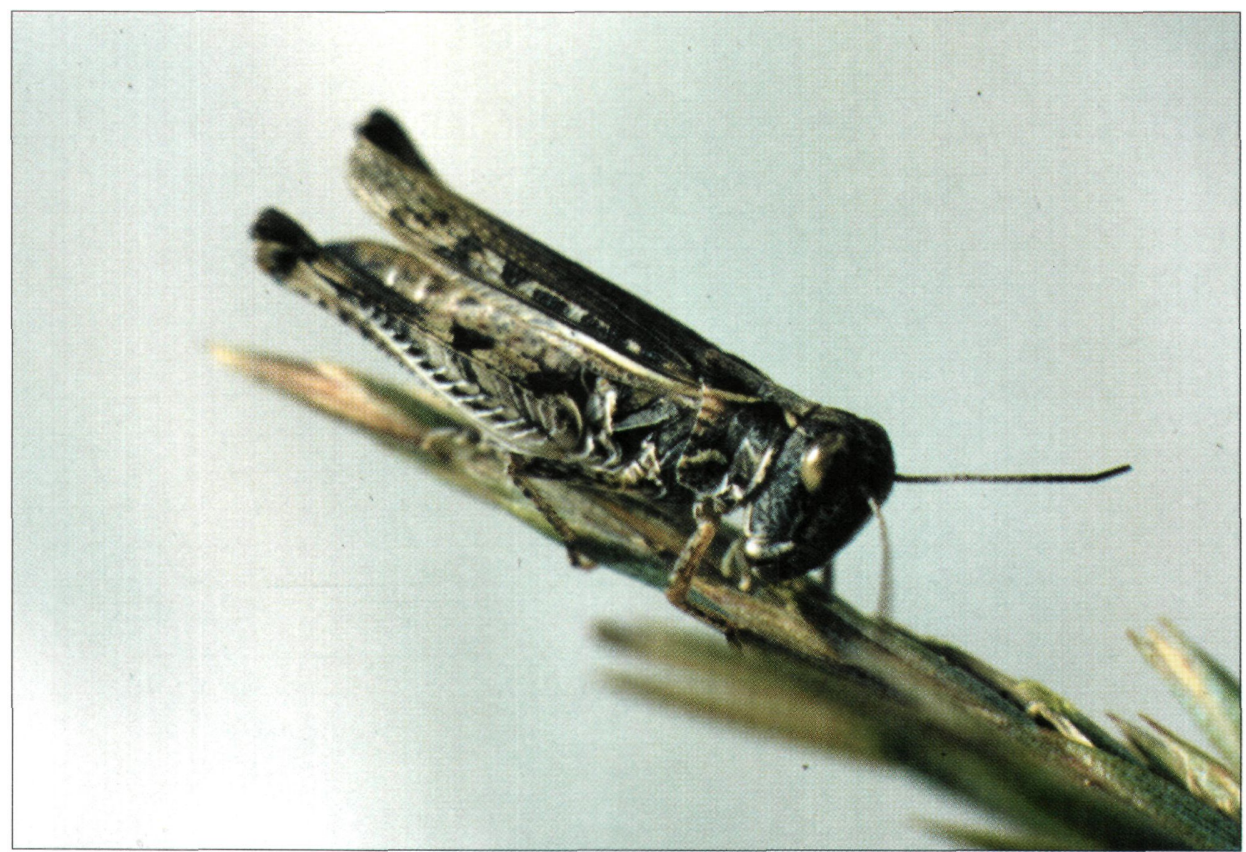

6. ábra: Rövidnyakú sáska (Dociostaurus brevicollis) nősténye. Pusztai faj, amely a Kárpát-medencétől északabbra már nem hatol. Fotó: Nagy B. 


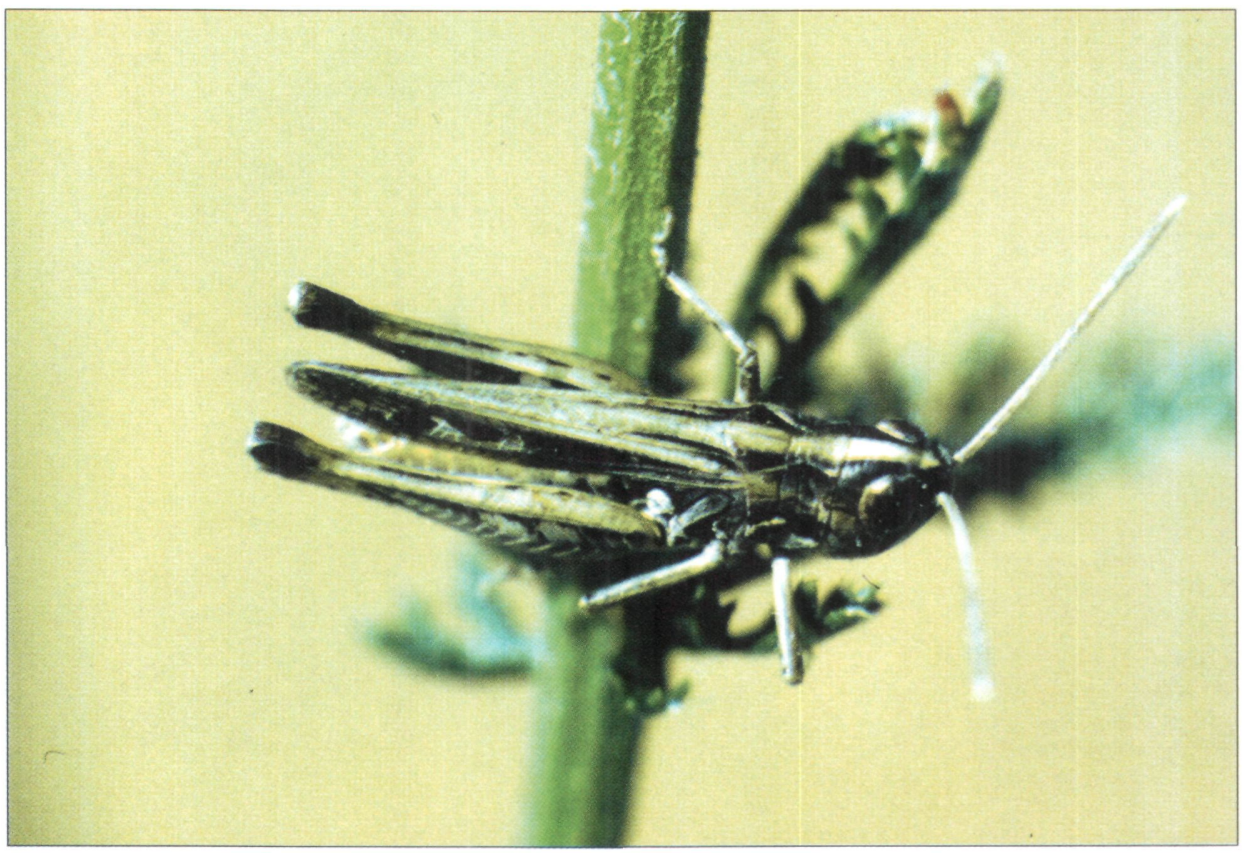

7. Szőke tarlósáska (Omocestus petraeus) hímje. Rövid-gyepes, száraz pusztai élóhelyek apró sáskája, ezért a látrányi területen csak kis foltokon fordul elő. Fotó: Nagy B.

\section{4. táblázat. Tölgyes bozótos szegélye (ökoton)} kimutatott fajok (+)

\begin{tabular}{|c|c|c|c|c|}
\hline Dátum/ Felvételi napló száma & 2000. szept. 14/1. & 2000. szept. $14 / 7$. & \begin{tabular}{|l|}
2002 .aug.28/3. \\
\end{tabular} & 2002.aug.28/7a \\
\hline \multicolumn{5}{|l|}{ Ensifera } \\
\hline Conocephalus discolor & & + & & \\
\hline Ruspolia nitidula & & + & & \\
\hline Meconem a meridionale & + & & & + \\
\hline Phaneroptera falcata & + & & & + \\
\hline Phaneroptera nana & & & + & \\
\hline Pholidoptera griseoaptera & + & & + & \\
\hline \multicolumn{5}{|l|}{ Caelifera } \\
\hline Pezotettix giornae & & + & + & \\
\hline Chorthippus brunneus & + & + & & \\
\hline Chorthippus dorsatus & & & + & \\
\hline Chorthippus parallelus & & & + & \\
\hline Euchorthippus declivus & + & & & + \\
\hline Gomphocerippus rufus & & + & & \\
\hline Fajszám & 5 & 5 & 5 & 3 \\
\hline
\end{tabular}




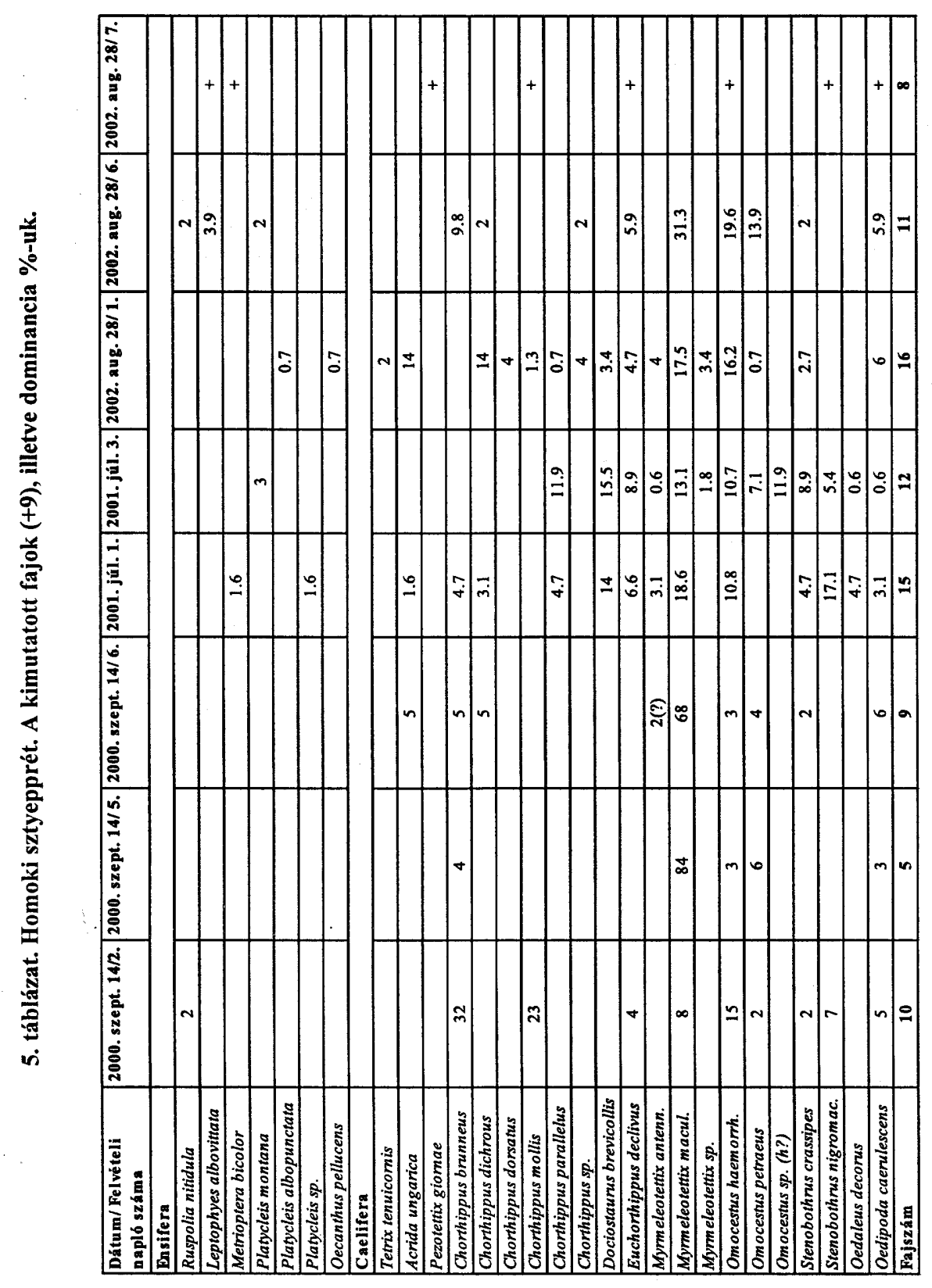

\section{Dominancia viszonyok}

$\mathrm{Az}$ Orthoptera-együtteseken belül a fajok százalékos részvétele igen szórt képet mutat. Az együtteseket alkotó fajok között mindössze 2-3 általánosan elterjedt (többnyire eurázsiai) olyan fajt találtunk, melyek dominanciája meghaladta a 25-30 \%-ot (Chorthippus brunneus, Ch. parallelus, Myrmeleotettix maculatus és Euchorthippus declivus). A fajok többségének az együttesekben való részesedése az 5-10 \%-os domi- 
6. táblázat. Rét (Cynodon), kaszálórét. A kimutatott fajok (+), illetve dominancia \%-uk.

\begin{tabular}{|l|c|c|}
\hline Dátum/ Felvételi napló száma & 2000.szept.14/3. & 2002. aug. 28/4. \\
\hline Ensifera & & \\
\hline Ruspolia nitidula & & + \\
\hline Pachytrachis gracilis & & + \\
\hline Caelifera & & \\
\hline Pezotettix giornae & & + \\
\hline Chorthippus brunneus & 4 & \\
\hline Chorthippus dichrous & 2 & \\
\hline Chorthippus dorsatus & 2 & \\
\hline Chorthippus mollis & 6 & + \\
\hline Chorthippus parallelus & & + \\
\hline Chrysochraon dispar & & + \\
\hline Euchorthippus declivus & & \\
\hline Myrmeleotettix maculatus & $\mathbf{7 2}$ & \\
\hline Omocestus haemorrhoidalis & 4 & $\mathbf{6}$ \\
\hline Omocestus petraeus & 7 & \\
\hline Oedipoda caerulescens & 3 & \\
\hline Fajszám & $\mathbf{8}$ & \\
\hline
\end{tabular}

nancia-érték alatt maradt. Egy-egy faj dominancia-értékeinek ugyanazon élöhely-típuson belüli jelentös eltérései arra engednek következtetni, hogy az egyes habitatok Orthoptera-együtteseinek faji összetételét lokális ökológiai tényezök (a növényzet szerkezete, a habitatok szomszédsága, zavartsági állapota, stb.) erősen befolyásolják. Ily módon szinte minden egyes habitat, és ennek megfelelően Orthoptera-együttese is nagy mértékben egyedi jelenség.

\section{Természetvédelmi vonatkozások}

A hazai természetvédelmi törvény szerint védett Orthoptera-fajként az LP-területén csupán az egyetlen ACRIDA UNGARICA sáska fordul elő, azonban e faj lokális jelentőségét emeli az a körülmény, hogy itteni jelenléte elterjedésének legészaknyugatibb határához közelít (ÁBRAHÁM 1992, NAGY és SZÖVÉNYI 2001). A Balaton vonalától ÉNy-ra nem számítva a jelenleg már kétségessé vált Tihany-félszigeti előfordulást (NAGY 1948) - csak néhány pontról ismeretes. Ennek ellenére természetvédelmi státusának fenntartása végett aligha szükséges külön beavatkozás, mert egyrészt ökológiai "türőképessége" folytán még zavart (homoki) parlag-területeken is megél, másrészt közepes repülö képessége folytán súlyosabb lokális zavarás estén könnyebben képes rekolonizációra.

\section{Köszönetnyilvánítás}

Köszönettel tartozunk Kondorosy Elödnek, aki több alkalmi gyüjtéssel gyarapította vizsgálati anyagunkat. Szentkirályi Ferenc és Kinál Ferenc ugyancsak segítettek a gyüjtésben. A helyszín felkeresésében és bejárásában Rozner György nyújtott értékes útmutatást. 
7. táblázat. Kékperjés (láp)rét. A kimutatott fajok (+), illetve dominancia \%-uk.

\begin{tabular}{|l|c|c|c|}
\hline $\begin{array}{l}\text { Dátu m/ Felvé teli } \\
\text { napló száma }\end{array}$ & 2001. júl. 2. & 2002. aug. 28: 2. & 2002. aug. 28: 5. \\
\hline Ensifera & \multicolumn{3}{|l|}{} \\
\hline Conocephalus discolor & $6,5(?)$ & + & + \\
\hline Ruspolia nitidula & & + & + \\
\hline Metrioptera bicolor & 6.5 & & \\
\hline Platycleis montana & 3.2 & & \\
\hline Tettigonia viridissima & 6.5 & & \\
\hline Caelife ra & & + & + \\
\hline Tetrix sp. & & & + \\
\hline Pezotettix giornae & & & + \\
\hline Chorthippus dichrous & 19.3 & + & \\
\hline Chorthippus dorsatus & & & \\
\hline Chorthippus parall.s & 51.5 & & \\
\hline Chrysochraon dispar & 6.5 & & \\
\hline Fajszám & 7 & & \\
\hline
\end{tabular}

8. táblázat. Vegyes élöhelyek. A kimutatott fajok (+), illetve dominancia \%-uk.

\begin{tabular}{|c|c|c|c|c|}
\hline Dátum/Felvételi napló száma & 2001. júl. 4. & 2001. júl. 5. & 2002. júl. 19/1. & 2002. júl. 19/2. \\
\hline \multicolumn{5}{|l|}{ Ensifera } \\
\hline Conocephalus discolor & & 7.1 & & \\
\hline Meconem a meridion. & & & 5.3 & \\
\hline Meconema sp. & 4.7 & & & \\
\hline Leptophyes albovittata & 4.7 & & & 20 \\
\hline Phaneroptera sp. & 4.7 & & & 10 \\
\hline Metrioptera bicolor & 14.5 & & 10.5 & \\
\hline Platycleis montana & 4.7 & 7.1 & 10.5 & \\
\hline \multicolumn{5}{|l|}{ Caelifera } \\
\hline Chorthippus brunneus & 14.5 & & & \\
\hline Chorthippus dichrous & & 14.3 & & \\
\hline Chorthippus parall. & 14.5 & 14.3 & 15.8 & 60 \\
\hline Dociostaurus brevic. & & 21.5 & & \\
\hline Euchorhippus declivus & 23.6 & 14.3 & 36.8 & 10 \\
\hline Myrmeleotettix macul. & & 14.3 & & \\
\hline Omocestus haemorrh. & $4,7(?)$ & 7.1 & 5.3 & \\
\hline Stenobothrus crassipes & 4.7 & & & \\
\hline Stenobothrus nigroma. & 4.7 & & 15.8 & \\
\hline Fajszám & 11 & 8 & 7 & 4 \\
\hline
\end{tabular}




\section{9. táblázat. A Bikács (Tolna m.) melleti Ökör-hegy Orthoptera-fajai 1995. júliusi vizsgálat alapján (dominancia \%)}

\begin{tabular}{|c|c|c|c|c|}
\hline Dátum/ Felvételi napló száma & 1995. júl. 26./1 & 1995. júl. 26./1a & 1995. júl. 26./5 & 1995. júl. 26./(5/1) \\
\hline \multicolumn{5}{|l|}{ Ensifera } \\
\hline Leptophyes albovittata & 1,7 & 2,2 & & 1,9 \\
\hline Platycleis montana & & 1,1 & & \\
\hline Platycleis affinis & & 0,5 & & \\
\hline Platycleis vittata & & & 4,2 & \\
\hline Oecanthus pellucens & 54,4 & 11,6 & & 1,9 \\
\hline \multicolumn{5}{|l|}{ Caelifera } \\
\hline Acrida ungarica & & & & 15 \\
\hline Calliptam us barbarus & & 7,8 & & 11,3 \\
\hline Calliptamus italicus & & 6,0 & & \\
\hline Chorthippus albomarginatus & & & 4,2 & \\
\hline Chorthippus brunneus & & & & 11,3 \\
\hline Chorthippus dichrous & & & 33,2 & 3,8 \\
\hline Dociostaurus brevicollis & & 0,4 & 4,2 & 20,8 \\
\hline Euchorhippus declivus & & 0,5 & 4,2 & 3,8 \\
\hline Euchorhippus pulvinatus & 42,2 & 50,1 & 4,2 & 5,7 \\
\hline Myrmeleotettix antennatus & & 6,0 & & \\
\hline Myrmeleotettix maculatus & & & & 7,5 \\
\hline Omocestus haemorrhoidalis & & 4,1 & 20,8 & \\
\hline Omocestus petraeus & 1,7 & 0,5 & 20,8 & \\
\hline Stenobothrus crassipes & & 4,8 & 4,2 & 1,9 \\
\hline Stenobothrus fischeri & & 0,7 & & \\
\hline Stenobothrus nigromaculatus & & 1,5 & & \\
\hline Celes variabilis & & 1,9 & & \\
\hline Oedaleus decorus & & 0,7 & & 5,7 \\
\hline Oedipoda caerulescens & & & & 9,4 \\
\hline Fajszám: & 4 & 17 & 9 & 13 \\
\hline
\end{tabular}

\section{Irodalom}

ARADI M. 1955: A Kis-Alföld Orthoptera faunájáról (Orthoptera - Saltatoria). - Folia Entom. Hun. 8: 95-110.

ÁBRAHÁM L. 1992: A sisakos sáska (Acrida hungarica, Herbst 1786) a Boronka-melléki Tájvédelmi Körzet környékén. - Dunántúli Dolg. Term. Tud. Sorozat 7: 99-100.

ÁBRAHÁM L. (szcrk.) 2001: Somogy megye faunakatalógusa. - Nat. Somogy. 1., Kaposvár.

Heller, K.-G. - Korsunovskaya, O. - RagGe, D.R. - Vedenina, V. - Willemse, F. - Zhantiev, R.D. FRANTSEVICH, L. 1998: Check-List of European Orthoptera. - Articulata - Beiheft 7: 1-61.

Kleukers, R. - VAN Nieukerken, E. - Odé, B. - Willemse, L. - Wingerden, W. (1997): De sprinkhanen en krckels van Nederland (Orthoptera). - Nederlandse fauna I. - Nationaal Natuurhist. Mus., Leiden

NAGY, B (1948): On the Orthoptera fauna of the Tihany peninsula (Lake Balaton, Western Hungary). - Arch. Biol. Hung., Ser. 11, 1859-64.

NAGY B. (2001): A déli dobolószöcskc (Mcconema meridionalc Costa, 1860) észak-kelet felé terjedésének első jelei Magyarországon (Orthoptcra: Tettigonioidea). - Folia Ent. Hung. 62: 319-414.

NAGY B. - SZÖVÉNYI G. (2001): Somogy megye egyenesszárnyú rovarai (Orthoptera). - Natura Somogyiensis 1: 107-117.

RÁcz 1. (1979): A Bakony hegysćg egyenesszárnyú (Orthoptera) faunájának alapvetése. - Veszprém Megyei Múz. Közl. 14: 95-114.

SzIRÁKI GY. (1996): Mcconema meridionale Costa, 1860 (Orthoptera: Tettigoniidac) - Magyarország faunájára új szöcskefaj a Zselici Tájvédelmi Körzetböl. - Folia cnt. hung. 57: 316-317. 
10. táblázat. A Látrányi Puszta Természetvédelmi Terület Orthoptera-fajainak jegyzéke. ***Védett faj, **Lokálisan ritka faj, * Állatföldrajzilag értékes faj

\begin{tabular}{|c|c|c|}
\hline \multirow[t]{2}{*}{ Sorsz. } & Fajnév & Magyar név \\
\hline & Ensifera & Tojócsövesek \\
\hline 1. & Conocephalus discolor & Kis kúpfejûszöcske \\
\hline 2. & Ruspolia nitidula & Nagy kúpfejûszöcske \\
\hline 3. & Meconema meridionale* & Déli dobolószöcske \\
\hline 4. & Leptophyes albovittata & Közönséges virágszöcske \\
\hline 5. & Phaneroptera falcata & Zöld repülõszöcske \\
\hline 6. & Phaneroptera nana* & Pontozott repülõszöcske \\
\hline 7. & Metrioptera bicolor & Halványzöld rétiszöcske \\
\hline 8. & Pachytrachis gracilis** & Karcsú szöcske \\
\hline 9. & Pholidoptera griseoaptera & Szürke avarszöcske \\
\hline 10. & Platycleis montana ${ }^{*}$ & Homokpusztai szöcske \\
\hline 11. & Platycleis albopunctata & Szürke rétiszöcske \\
\hline 12. & Tettigonia viridissima & Zöld lombszöcske \\
\hline \multirow[t]{2}{*}{13.} & Oecanthus pellucens & Pirregõtücsök \\
\hline & Caelifera & Tojókampósok \\
\hline 14. & Tetrix tenuicomis & Vékonycsápú tövishátúsáska \\
\hline 15. & Acrida ungarica *** & Sisakos sáska \\
\hline 16. & Pezotettix giornae* & Kis hegyisáska \\
\hline 17. & Chorthippus brunneus & Közönséges tarlósáska \\
\hline 18. & Chorthippus dichrous* & Vállas rétisáska \\
\hline 19. & Chorthippus dorsatus & Hátas rétisáska \\
\hline 20. & Chorthippus mollis & Halk tarlósáska \\
\hline 21. & Chorthippus parallelus & Közönséges rétisáska \\
\hline 22. & Chrysochraon dispar & Aranyos sáska \\
\hline 23. & Dociostaurus brevicollis** & Rövidnyakú sáska \\
\hline 24. & Euchorthippus declivus & Rövidszárnyú rétisáska \\
\hline 25. & Gomphocerippus rufus & Erdei bunkóscsápúsáska \\
\hline 26. & Myrmeleotettix antennatus* & Homoki bunkóscsápúsáska \\
\hline 27. & Myrmeleotettix maculatus & Kis bunkóscsápúsáska \\
\hline 28. & Omocestus haemorrhoidalis & Barna tarlósáska \\
\hline 29. & Omocestus petraeus* & Szõke tarlósáska \\
\hline 30. & Stenobothrus crassipes & Rövidszárnyú rét isáska \\
\hline 31. & Stenobothrus nigromaculatus & Sztyeppréti sáska \\
\hline 32. & Oedaleus decorus* & Szalagos sáska \\
\hline 33. & Oedipoda caerulescens & Kékszárnyú sáska \\
\hline
\end{tabular}




\section{Összefoglalás}

A 223,6 ha kiterjedésű Látrányi Puszta Természetvédelmi Területről - 2000-2002 évi gyüjtések alapján - 33 Orthoptera-fajt mutattunk ki. Faunisztikai, állatföldrajzi tekintetben figyelemre méltóbb Orthoptera-együtteseket (pl. a Myrmeleotettix antennatus, Platycleis montana, Omocestus petraeus fajokkal) csak a korlátozott kiterjedésü, alacsony homokdombok, részben zavart/másodlagos homokpusztai élöhelyein találtunk. Azonban ezen Orthoptera-együttesekböl jórészt hiányoznak a Duna-Tisza-közi kiterjedtebb homokpuszták Orthoptera-együtteseire oly jellemző homokpusztai karakter-fajok (pl. Stenobothrus fischeri, Acrotylus, Calliptamus barbarus, Sphingonotus, stb.), amelyek viszont a kb. 60 km-rel K-ebbre lévö bikácsi Ökör-hegyen már megvannak. Állatföldrajzilag figyelemre méltó, hogy a LP területén találtuk meg a Meconema meridionale harmadik magyarországi lelőhelyét, ami e faj ÉK-re való elörenyomulására utal. A Pachytrachis gracilis jelenléte a Balaton északi oldalán lévő dombok faunájára emlékeztet. A kis kiterjedésü, de eltérö ökológiai jellegü élőhely-típusok mozaikos megjelenése - különösen a repülni tudó fajok esetében (Phaneroptera, Ruspolia) - néhány faj szokatlan ökológiai környezetben való előfordulásához vezet. A lokális Orthoptera fauna egyetlen védett kategóriába tartozó faja az Acrida ungarica a Dunántúlon csak ritkán, kisebb elszigetelt foltokban fordul elő.

\section{Grasshoppers (Orthoptera) of the Látrányi Puszta Nature Conservation Area (South Hungary)}

\section{Barnabás Nagy, Gergely Szövényi \& Gellért Puskás}

The Látrányi Puszta Nature Conservation Area (LP, West Hungary, 223.6 ha) is not well separated from its surrounding. Low sandy hills with xerophilous vegetation (partly secondary and disturbed by grazing) are here the most important habitats for grasshoppers, however, a mosaic of these and of small mesophilous meadows and swampy places enable the occurrence of other, mostly common species, too. Among the 33 Orthoptera species detected during 2000-2002, only Myrmeleotettix antennatus (and in lesser extent the Platycleis montana, Omocestus petraeus and Acrida ungarica) represents here a richer and more typical assembly of the extensive sandy grassland region between the river Danube and Tisza (in a distance of about $90 \mathrm{~km}$ to E).

However, there is another isolated sandy hill (about $65 \mathrm{~km}$ E from LP), where the grasshopper assembly contains nearly all characteristic "sandy" species (such as Stenobothrus fischeri. Acrotylus insubricus, Sphingonotus caerulans, Calliptamus barbarus, etc.). Therefore, the low number of characteristic indicator "sandy" species in the xerophilous assembly found in the LP may need other explanation.

Among zoogeographically interesting species in the LP, Arcrida ungarica should be mentioned. This species is protected by law in Hungary. It occurs in the most NW zone of Hungary. LP represents the third occurrence of the Meconema meridionale in Hungary, a sign of the area extension of this species towards the continental NE. 